\title{
PEMANTAUAN KARAKTERISTIK KEBIASAAN CUCI TANGAN SEBAGAI UPAYA PENCEGAHAN HEPATITIS A DI PESANTREN SABILUNNAJAT
}

\section{INVESTIGATION CHARACTERISTICS OF HAND WASH HABITS AS A PREVENTION OF HEPATITIS A IN SABILUNNAJAT ISLAMIC BOARDING SCHOOL}

\author{
${ }^{1)}$ Triana Srisantyorini ${ }^{*},{ }^{2}$ Suherman, $\left.{ }^{3}\right)$ Wulan Askiani \\ ${ }^{1,2,3)}$ Program Studi Kesehatan Masyarakat, Fakultas Kesehatan Masyarakat \\ Universitas Muhammadiyah Jakarta \\ Jl. KH. Ahmad Dahlan, Cireundeu, Ciputat, Tangerang Selatan \\ *Email: triana.srisantyorini @umj.ac.id
}

\begin{abstract}
ABSTRAK
Terjadi kejadian luar biasa kasus hepatitis A di Jawa Barat dengan 188 kasus tahun 2018. Hepatitis A masih banyak terjadi di negara negara berkembang seperti Indonesia. Salah satu faktor yang berhubungan dengan kejadian hepatitis A yaitu personal higiene yaitu kebiasaan cuci tangan. Tinggi nya angka kasus hepatitis A ini menjadi permasalahan yang diangkat untuk menjadi tujuan dari pengabdian masyarakat dengan cara meneliti dan memberikan penyuluhan mengenai pencegahan hepatitis A dengan melakukan pemantauan karakteristik kebiasaan mencuci tangan di Pesantren Sabilunnajat. Hasil dari penelitian yang kami lakukan didapatkan hasil bahwa 64,1\% santri mempunyai kebiasaan selalu mencuci tangan pakai sabun. sebagian besar santri sudah mencuci tangan dengan air mengalir dengan pesentase 93,2\%. 81,3\% santri memiliki kebiasaan mencuci tangan sebelum menyiapkan makanan/sebelum makan. Saran yang kami berikan ke pihak manajemen pesantren adalah diadakannya penyuluhan kesehatan terkait kebiasaan cuci tangan khususnya dan personal higiene pada umumnya.
\end{abstract}

Kata kunci: cuci tangan, hepatitis A, pencegahan

\begin{abstract}
An outbreak of hepatitis A cases occurred in West Java with 188 cases in 2018. Hepatitis A still occurs in developing countries like Indonesia. One factor related to the occurrence of hepatitis $A$ is personal hygiene that is hand washing habits. The high number of cases of hepatitis $A$ is a problem that was raised to be the goal of community service by researching and providing counseling about prevention of hepatitis A by monitoring the characteristics of hand washing habits at the Sabilunnajat Islamic boarding school. The results of our observers showed that $64.1 \%$ had a habit of always washing hands with soap. most of the students had washed their hands with running water with a percentage of $93.2 \% .81 .3 \%$ of students have the habit of washing their hands before preparing food / before eating. The advice we give to the management is the holding of health education related to hand washing habits in particular and personal hygiene in general.
\end{abstract}

Keywords: washing hands, hepatitis A, prevention 


\section{PENDAHULUAN}

Kasus hepatitis A pernah menjadi kasus kejadian luar biasa sebanyak 9 kali tahun 2018 di Indonesia dengan jumlah kasus mencapai 564 kasus. Sebagian besar terjadi di Provinsi Jawa Barat dengan jumlah kasus sebanyak 188 kasus. Hepatitis A masih banyak terjadi negara negara berkembang seperti Indonesia. Penularan kasus ini melalui fecal oral yaitu melalui makanan dan minuman yang terkontaminasi agent hepatitis A. (Kemenkes, 2019)

Upaya pencegahan penyakit pada khususnya kasus hepatitis A seyogyanya dilakukan secara sistematis. Baik ditingkat pencegahan primer, sekunder dan tersier. Perilaku hidup bersih dan sehat, personal higiene harus membudaya disetiap tempat terkhusus pada pesantren. Pengadaan dari sumber air bersih, sistem distribusi air yang benar juga harus terintegrasi dalam pencegahan hepatitis A. Pesantren merupakan tempat berisiko untuk beberapa kejadian penyakit antara lain hepatitis A. Penyakit tersebut dapat dicegah dengan praktik cuci tangan menggunakan sabun sebagai salah satu bentuk personal higiene. Dampak yang akan terjadi jika tidak dilakukan pencegahan yang sistematis adalah salah satunya dengan melakukan Perilaku Hidup Bersih dan Sehat (PHBS) dalam kehidupan sehari-hari. Penyakit ini mudah menular pada setiap orang maka dapat mengkibatkan Kejadian Luar Biasa (KLB) (Masriadi, 2014). Selain dari personal higiene, terdapat risiko pada seseorang apabila belum diimunisasi hepatitis A serta terbiasa tukar menukar alat dan makan bersama dalam satu tempat adalah 3,36 kali untuk terjadinya hepatitis A. (Sumarni I, Susanna D, 2014)

Pesantren Sabilunnajat merupakan pesantren yang terletak di desa Rancah Cileungsir, Ciamis. Pemantauan awal yang kami dapatkan belum ada unit kesehatan pesantren di pesantren ini. Hasil dari penuturan pengurus pesantren, penyakit yang pernah dialami oleh santri antara lain penyakit kulit dan hepatitis A. Salah satu cara pencegahan dengan melakuan personal higiene dalam bentuk cuci tangan pakai sabun dengan air bersih yang mengali yang merupakan salah satu dari indikator perilaku hidup bersih dan sehat. Pengabdian masyarakat ini kami melakukan pemantauan bagaimana cara santri di Pesantren Sabilunnajat praktik melakukan cuci tangan. Langkah ini sebagai bentuk awal kami dalam pengabdian masyarakat di Pesantren tersebut. Pada lingkungan pesantren sebenarnya sudah melaksanakan cuci tangan dalam aktifitas berwudhu minimal 5 waktu dalam rangkaian sholat wajib, akan tetapi mengapa penyakit tersebut dapat terjadi. Maka kami melakukan pemantauan karakteristik praktik cuci tangan di Pesantren Sabilunnajat. Tujuan dari pengabdian masyarakat ini adalah untuk mengetahui bagaimana praktik santri dalam mencuci tangan, dan dari hasil pemantauan awal ini akan kamis jadikan sebagai bahan acuan untuk intervensi selanjutnya.

\section{METODE}

Pemantauan praktik kebiasaan mencuci tangan ini dilaksanakan di Pesantren Sabilunnajat, Ciamis, pada tanggal 21-23 Februari 2020. Kami melibatkan mahasiswa untuk membantu pelaksanaan pengabdian masyarakat ini sebagai asisten lapangan. Sebelum melaksanakan pemantauan kami melakukan pelatihan untuk asisten lapangan terkait cara pemantauan pengabdian masyarakat ini. Alat ukur yang digunakan dengan menggunakan kuesioner dan observasi langsung. Mitra pada pengabdian masyaraakat ini adalah pengurus Pondok Pesantren Sabilunnajat. Pengabdian masyarakat dimulai dari pelatihan asisten lapangan, lalu turun lapangan, mengukur hasil pemantauan dan desiminasi hasil pengabdian masyarakat. Alat yang digunakan adalah kuesioner yang telah valid. 


\section{HASIL DAN PEMBAHASAN}

Pada bagian ini kami memaparkan hasil pemantauan yang telah kami lakukan di Pesantren Sabilunnajat yang dibantu mahasiswa dari Program Studi Kesehatan Masyarakat Fakultas Kesehatan Masyarakat Universitas Muhammadiyah Jakarta.

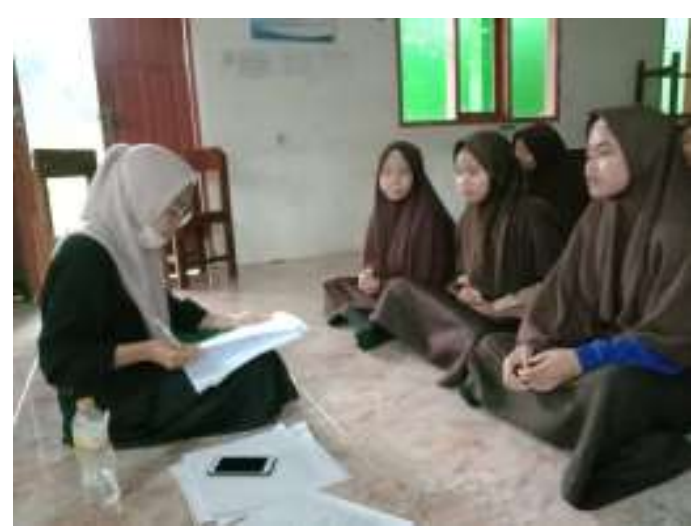

Sumber: Data primer 2020

Gambar 1. Wawancara terhadap kebiasaan mencuci tangan pada santri di Pesantren Sabilunnajat.

Tabel 1. Kebiasaan Selalu Mencuci Tangan Pakai Sabun pada santri di Pesantren Sabilunnajat Ciamis 2020

\begin{tabular}{lrc}
\hline Kebiasan selalu mencuci tangan pakai sabun & $\mathrm{n}$ & Persentasi \\
\hline Ya & 116 & 64,1 \\
Tidak & 65 & 35,9 \\
\hline Total & 181 & 100,0 \\
\hline
\end{tabular}

Sumber: Data Primer, 2020

Hasil dari pemantauan kami tentang kebiasaan mencuci tangan pakai sabun pada santri di Pesantren Sabilunnajat didapatkan hasil bahwa 64,1\% mempunyai kebiasaan selalu mencuci tangan pakai sabun sedangkan sisanya 35,9\% tidak mempunyai kebiasaan selalu mencuci tangan pakai sabun. Dalam hasil studi lain menyatakan bahwa $45 \%$ tidak mencuci tangan pakai sabun. Hanya 55\% yang mencuci tangan pakai sabun (Sumarni I, Susanna D, 2014).

Tabel 2. Kebiasaan Selalu Mencuci Tangan dengan Air yang Mengalir pada Santri di Pesantren Sabilunnajat Ciamis 2020

\begin{tabular}{lrc}
\hline Kebiasan selalu mencuci tangan dengan air yang mengalir & $\mathrm{n}$ & persentasi \\
\hline Ya & 165 & 93,2 \\
Tidak & 12 & 6,8 \\
\hline Total & 192 & 100,0 \\
\hline
\end{tabular}

Sumber: Data Primer, 2020

Dari tabel diatas didapatkan informasi bahwa hasil pemantauan yang dilakukan di Pesantren Sabilunnajat Ciamis sebagaian besar santri sudah mencuci tangan dengan air mengalir dengan pesentase 93,2\%. Hanya 6,8 persen yang tidak selalu mencuci tangan dengan air yang mengalir. Kebiasaan mencuci tangan pada air yang mengalir tidak dapat 
melindungi host dari virus maupun bakteri. Maka harus dirubah lebih baik menjadi cuci tangan menggunakan sabun dengan tujuh Langkah.

Tabel 3. Kebiasaan Mencuci Tangan Sebelum Menyiapkan Makanan/Sebelum Makan pada Santri di Pesantren Sabilunnajat Ciamis 2020

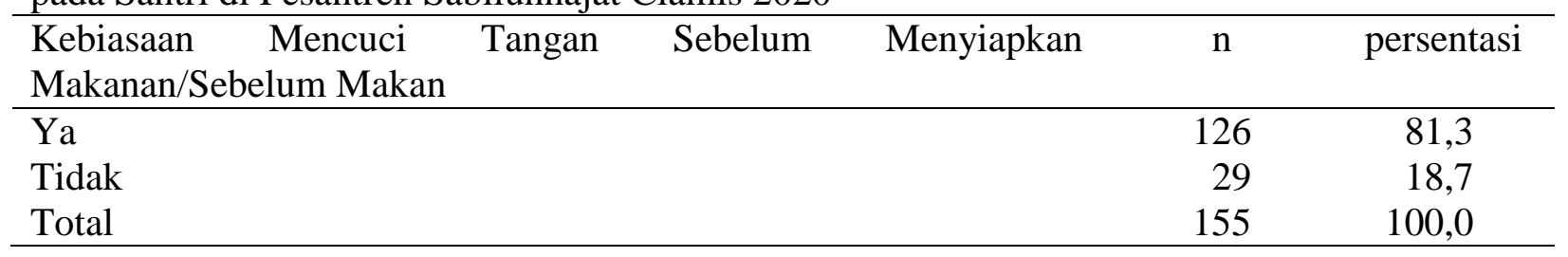

Sumber: Data Primer, 2020

Dari tabel diatas didapatkan informasi bahwa $81,3 \%$ santri memiliki kebiasaan mencuci tangan sebelum menyiapkan makanan/sebelum makan. Sedangkan 18,7\% tidak mempunyai kebiasaan mencuci tangan sebelum menyiapkan makan atau sebelum makan. Hasil studi lain menyatakan bahwa 24,2\% tidak mencuci tangan sebelum makan. (Sumarni I, Susanna D, 2014).

Pada studi yang pernah dilakukan sebelumnya dinyatakan ada hubungan antara tingkat pengetahuan dengan sikap cuci tangan sebelum dan sesudah makan pada siswa kelas 4, 5, dan 6 SDN Ngebel Tamantirto, Kasihan, Bantul, Yogyakarta. (Khoiruddin, Kirnantoro, Sutanta, 2015). Selain dari pada itu hasil studi yang penah dilakukan sebelumnya terdapat efektivitas promosi kesehatan cuci tangan oleh peer group terhadap pelaksanaan perilaku hidup bersih dan sehat di Pesantren Assalafi "Al Fithrah" Semarang. (Sari ER, Nuraeni A, Supriyono M. 2015). Maka kami akan agendakan untuk melakukan penyuluhan kesehatan dengan diskusi kelompok untuk pencegahan Hepatitis A.

\section{KESIMPULAN DAN SARAN}

Dari hasil pemantauan yang telah kami lakukan di Pesantren Sabilunnajat didapatkan beberapa hasil yaitu $64,1 \%$ mempunyai kebiasaan selalu mencuci tangan pakai sabun. sebagaian besar santri sudah mencuci tangan dengan air mengalir dengan pesentase 93,2\% . 81,3\% santri memiliki kebiasaan mencuci tangan sebelum menyiapkan makanan/sebelum makan. Saran yang kami berikan ke pihak Pesantren Sabilunnajat. adalah diadakannya penyuluhan kesehatan terkait kebiasaan cuci tangan khususnya dan personal higiene pada umumnya.

\section{UCAPAN TERIMA KASIH}

Kami memberikan penghormatan setinggi tingginya kepada pihak yang telah mendukung penuh acara pengabdian masyarakat ini dalam bentuk pemantauan kebiasaan mencuci tangan pada santri di Pesantren Sabilunnajat terutama pada pengurus Pondok Pesantren Sabilunnajat.

\section{DAFTAR PUSTAKA}

Kementerian Kesehatan RI. 2019. Sekretariat Jenderal. Profil Kesehatan Indonesia Tahun 2018. Jakarta : Kementerian Kesehatan RI.

Khoiruddin, Kirnantoro, Sutanta. 2015. Tingkat Pengetahuan Berhubungan dengan Sikap Cuci Tangan Bersih Pakai Sabun Sebelum dan Setelah Makan pada Siswa SD N Ngebel Tamantirta, Kasihan, Bantul, Yogyakarta. JNKI. Vol. 3. No. 3 
Masriadi. 2017. Epidemiologi Penyakit Menular. Rajawali Pers Divisi Buku Perguruan Tinggi PT Rajawali Grafindo Persada Depok.

Sari ER, Nuraeni A, Supriyono M. 2015. Efektifitas promosi kesehatan cuci tangan oleh peer group - terhadap pelaksanaan perilaku hidup bersih dan sehat di pesantren Assalafi "Al Fitrah" Semarang. Karya ilmiah. ejournal.stikestelogorejo.ac.id

Sumarni I, Susanna D. 2014. Kondisi Kesehatan Lingkungan Pesantren dan Perilaku Hidup Hidup Bersih dan Sehat Siswa dengan Kejadian Hepatitis. Kesmas, Jurnal Kesehatan Masyarakat Nasional Vol. 9, No. 2. Hal 179-186 